\title{
Microbeam evolution: From single cell irradiation to preclinical studies
}

Ghita, Mihaela; Fernandez-Palomo, Cristian; Fukunaga, Hisanori; Fredericia, Pil M.; Schettino, Giuseppe; Bräuer-Krisch, Elke; Butterworth, Karl T.; McMahon, Stephen J.; Prise, Kevin M.

Published in:

International Journal of Radiation Biology

Link to article, DOI:

$10.1080 / 09553002.2018 .1425807$

Publication date:

2018

Document Version

Peer reviewed version

Link back to DTU Orbit

Citation (APA):

Ghita, M., Fernandez-Palomo, C., Fukunaga, H., Fredericia, P. M., Schettino, G., Bräuer-Krisch, E., Butterworth, K. T., McMahon, S. J., \& Prise, K. M. (2018). Microbeam evolution: From single cell irradiation to preclinical studies. International Journal of Radiation Biology, 94(8), 708-718.

https://doi.org/10.1080/09553002.2018.1425807

\section{General rights}

Copyright and moral rights for the publications made accessible in the public portal are retained by the authors and/or other copyright owners and it is a condition of accessing publications that users recognise and abide by the legal requirements associated with these rights.

- Users may download and print one copy of any publication from the public portal for the purpose of private study or research.

- You may not further distribute the material or use it for any profit-making activity or commercial gain

- You may freely distribute the URL identifying the publication in the public portal 


\title{
Microbeam evolution: From single cell irradiation to preclinical studies
}

\author{
Mihaela Ghita, Cristian Fernandez-Palomo, Hisanori Fukunaga, Pil M. \\ Fredericia, Giuseppe Schettino, Elke Bräuer-Krisch, Karl T. Butterworth, \\ Stephen J. McMahon \& Kevin M. Prise
}

To cite this article: Mihaela Ghita, Cristian Fernandez-Palomo, Hisanori Fukunaga, Pil M. Fredericia, Giuseppe Schettino, Elke Bräuer-Krisch, Karl T. Butterworth, Stephen J. McMahon \& Kevin M. Prise (2018): Microbeam evolution: From single cell irradiation to preclinical studies, International Journal of Radiation Biology, DOI: 10.1080/09553002.2018.1425807

To link to this article: https://doi.org/10.1080/09553002.2018.1425807

Accepted author version posted online: 08 Jan 2018.

\section{Submit your article to this journal $\square$}

Џ Article views: 1

Q View related articles $\square$

View Crossmark data $\subset$ 


\section{Microbeam evolution: From single cell irradiation to preclinical studies}

Mihaela Ghita ${ }^{1}$, Cristian Fernandez-Palomo ${ }^{2}$, Hisanori Fukunaga ${ }^{1}$, Pil M. Fredericia ${ }^{3}$,

Giuseppe Schettino ${ }^{4}$, Elke Bräuer-Krisch ${ }^{5}$, Karl T. Butterworth ${ }^{1}$, Stephen J. McMahon ${ }^{1}$ and Kevin M. Prise ${ }^{1}$

(1)Centre for Cancer Research and Cell Biology, Queen's University Belfast, 97 Lisburn Road, Belfast, BT9 7AE, UK (2) Institute of Anatomy, University of Bern, Baltzerstrasse 2 CH-3000 Bern 9, Switzerland, (3) Centre for Nuclear Technologies, Technical University of Denmark, Frederiksborgvej 399, 4000 Roskilde, Denmark, (4) National Physical Laboratory, Hampton Road, Teddington, Middlesex, TW11 OLW. (5) European Synchrotron Radiation Facility, 71 Avenue des Martyrs, 3800, Grenoble, France.

Keywords: Microbeam, DNA damage, MRT, bystander effects of radiation

* Corresponding author

Dr Mihaela Ghita

Centre for Cancer Research and Cell Biology

Queen's University Belfast

97 Lisburn Road

BT9 7AE

Belfast

Northern Ireland, UK

Tel: 00442890972307

Fax: 00442890972776

Email:m.ghita@qub.ac.uk 


\section{Abstract}

Purpose

This review follows the development of microbeam technology from the early days of single cell irradiations, to investigations of specific cellular mechanisms and to the development of new treatment modalities in vivo. A number of microbeam applications are discussed with a focus on preclinical modalities and translation towards clinical application.

\section{Conclusions}

The development of radiation microbeams has been a valuable tool for the exploration of fundamental radiobiological response mechanisms. The strength of micro-irradiation techniques lies in their ability to deliver precise doses of radiation to selected individual cells in vitro or even to target subcellular organelles. These abilities have led to the development of a range of microbeam facilities around the world allowing the delivery of precisely defined beams of charged particles, X-rays, or electrons.

In addition, microbeams have acted as mechanistic probes to dissect the underlying molecular events of the DNA damage response following highly localised dose deposition. Further advances in very precise beam delivery have also enabled the transition towards new and exciting therapeutic modalities developed at synchrotrons to deliver radiotherapy using plane parallel microbeams, in Microbeam Radiotherapy (MRT). 


\section{Introduction}

Biological damage induced by ionising radiation occurs due to chemical changes caused by ionisation at the cellular level. The classical radiobiology paradigm is that nuclear DNA is the primary target for biological damage. The amount of biological damage induced by ionising radiation depends on variables including dose, the rate of absorption, the exposed area, and the variations in radical species, between specific tissues and cells, and in radiosensitivity between individuals (Joiner \& van der Kogel 2009).

Ionising radiation has been successfully exploited in radiotherapy as a powerful cancer therapy, which has been significantly refined due to the accumulation of knowledge on its effects derived from new advances in epidemiology and radiobiology (Clement et al. 2012).

Continuous technological advances and new radiobiology challenges are behind the interest in the use of micro-irradiation techniques for radiobiological studies. Due to the very small beam size and highly precise targeting within the cell, microbeams have empowered researchers with unique investigative methods. In particular, the very precise dose delivery has played a fundamental role in the investigation of non-targeted effects where the radiation response is induced in cells which are not directly exposed to ionising radiation (Schettino et al. 2010). The technology has also recently contributed to the discovery of important novel time-sensitive interaction mechanisms of ionizing radiation with cells and tissues (Ghita et al. 2017; Walsh et al. 2017).

A number of technical features are vital to ensure that microbeams have the versatility and high specificity that is key for modern radiobiological experiments. These include the targeting accuracy, the particle counting efficiency, the dose rate and the rate at which cellular targets can be identified and irradiated. A wide range of facilities have been 
developed worldwide delivering charged particles (including protons and helium ions), Xrays, and electrons for a number of specific in vitro and in vivo applications.

Depending on the beam origin, modern microbeams are divided into either cyclotron or accelerator based (for particle microbeams), compact X-ray source based (e.g. soft X-ray), and synchrotron based facilities.

For basic radiobiological experiments where individual cells can be targeted, the key components of a microbeam are shown in figure 1 and include beam transport and microbeam producing devices, radiation detection, beam control, and cell dish design. These can be implemented in a number of different ways depending on the specific application of the facility. Microbeams are typically also equipped with an imaging station allowing the users to identify targets and align them with the radiation probe. They can also be used for following up the dynamics of cellular processes such as DNA damage and repair in real time. For beam size adjustment, different methods to reduce the beam size are employed depending on the target. Cell dish design and particle detection are strongly dependent on the beam species, carefully considering beam orientation, any possible beam scatter around the dish or the very thin penetration depth of the particular beam. These aspects have been previously discussed in an in depth review on technical aspects of microbeams (Schettino et al. 2010). In an alternative approach, synchrotron based microbeams deliver X-rays emitted tangentially from relativistic electron bunches circulating in a storage ring. The irradiation modality consists of an array of microbeams (25-100 $\mu \mathrm{m}$ width), created by inserting a multi-slit collimator in the path of the high-flux Synchrotron X-Rays (Bräuer-Krisch et al. 2009; Bouchet et al. 2016; Smyth et al. 2016).

Microbeam facilities have been used in a variety of models to unravel some of the early events occurring immediately after the localized DNA damage within irradiated cells and in adjacent non irradiated populations both in vitro and in vivo (Richard et al. 2011), (Buonanno 
et al. 2015) and (A Bertucci et al. 2009) . Recently, the technology has been used to elucidate bystander and abscopal effects in vivo (Fernandez-Palomo et al. 2015) using an array of microbeams and progressing towards the development of novel radiotherapy modalities: microbeam radiation therapy (MRT) (Bräuer-Krisch et al. 2015).

This review follows the development of microbeam technology from the early days of single cell irradiations to the development of new treatment modalities using microbeams focusing on preclinical developments and translation towards clinical applications

\section{Particle microbeams}

Microbeam approaches have been around since the early development of a UV microbeam by Tschachotin in 1912 (Wu \& Hei 2017). The first particle microbeam experiment was performed by Zirkle and Bloom in 1953 (Zirkle, Raymond \& William 1953) using a 2 MV Van de Graaf accelerator to generate energetic protons. Micro-collimators consisting of two metal plates, with a groove etched in one of them, were clamped together to achieve a beam size of $2.5 \mu \mathrm{m}$. This was used to study the process of cell division after proton exposure. From here, the development of modern microbeams has intensified in the early 1990s, with the early developments using the cyclotron facility at the Brookhaven National Laboratories used to simulate the biological effects of cosmic rays. These first observations of a dosevolume effect were the beginning of the later proposed MRT technique (W et al. 1959; Slatkin D N et al. 1992). Another pioneering study used the $2 \mathrm{MeV}$ tandem accelerator-based microbeam at Pacific Northwest Laboratories (Braby 1991).

Single cell charged particle microbeams can be grouped into two main categories according to the approach used to reduce the radiation beam to sub-cellular dimensions: microbeams using a collimation assembly and facilities employing electromagnetic focusing. 
Many of the early microbeams used collimation approaches, whereas electromagnetic focusing has recently become a more common approach reflecting both technological advances and the need for finer resolution to probe micron level interactions within cells (Schettino et al. 2010).

Collimators and apertures have been extensively used at pioneering facilities of modern radiobiological microbeams, including Pacific Northwest Laboratory, the Gray Cancer Institute and Columbia University. Using fused silica tubing with apertures as small as $1 \mu \mathrm{m}$ diameters, $90 \%$ protons and $99 \%{ }^{3} \mathrm{He}^{2+}$ were confined within a $2 \mu \mathrm{m}$ spot (Melvyn Folkard et al. 1997). Also, laser drilled apertures of 5-6 $\mu \mathrm{m}$ were used to achieve $5 \mu \mathrm{m}$ beams with $91 \%$ of non-scattered particles (Melvyn Folkard et al. 1997).

The electromagnetic focusing approach utilizes a variety of magnetic quadrupoles to obtain extremely narrow charged particle beams in vacuum. However, the focused beam has to be extracted in air, with a significant scattering induced by the vacuum window, air gap and traversal of the cell support membrane.

Electron microbeams rely on standard electron guns and electrostatic devices for beam generation. They produce and accelerate the energetic electron beams, which are subsequently reduced to micrometre size by the use of apertures or electromagnetic focusing (Sowa et al. 2005). As electrons undergo more scattering when interacting with biological samples compared to heavier charged particles, it is challenging for electron microbeams to achieve targeting resolutions at the micron or submicron level despite the size of the focused beam in vacuum. This poses challenges not only related to the resolution of electron microbeams but also to the calculation of the energy deposition and subsequent spatial dose distribution at the cellular level. These effects are not only significant for electron microbeams, but also for biological dosimetry of low energy electrons in general (Sowa et al. 2005; Siragusa et al. 2017). 
An overview of the facilities currently in operation, dedicated to biology or shared with analytical experiments, has recently been presented (Barberet \& Seznec 2015) and an update is shown in table 1.

\section{X-ray microbeams}

Considering the irradiation geometry, X-ray microbeams employ either a single beam or an array of microbeams. For cellular irradiation, single X-ray microbeams are used to specifically target subcellular compartments of the cells and analyse specific mechanisms behind cellular damage repair. However, there is growing interest in the preclinical setting of irradiation of in vivo tumours using arrays of microbeams with a more complex geometry and dose delivery. In addition to the beam geometry, the X-ray energy used and doses delivered will also vary between these two different types of microbeams (Folkard et al. 2001a) (Bouchet et al. 2010). A current list of soft X-ray and synchrotron microbeam facilities is presented in table 2.

Single X-ray microbeams have been developed, starting in the 1990s (Schettino et al. 1997) to provide quantitative and mechanistic radiobiological information to complement charged particle studies. Damage caused by X-rays delivered to a single cell is qualitatively different to lesions produced by charged particles due to reduced clustering of the ionizations (D. T. Goodhead 1994). As scattering is not as important, X-ray microbeams are, in theory, capable of achieving radiation spots of an order of magnitude or more, smaller than those achieved with ion beams. Moreover, such this high spatial resolution is maintained as the X-ray beam penetrates through cells making it possible to irradiate deeper targets with micron precision, making its therapeutic use feasible.

Modern X-ray microbeams employ benchtop based electron bombardment X-ray sources for energies from $278 \mathrm{eV}$ to $4.5 \mathrm{keV}$ (Schettino et al. 2000). In addition to characteristic 
radiation, the electron bombardment of the target will produce a continuum of bremsstrahlung with a maximum energy equivalent to the energy of the incident electrons. This radiation is undesirable because it will not be focused correctly, and can be significantly more penetrating than the characteristic X-rays. The bremsstrahlung component is removed by reflecting the radiation off a silica mirror mounted between the target and the focusing assembly (Schettino et al. 2000) For this type of soft X-ray microbeams very small probes can be achieved by the use of X-ray optics developed for high-resolution X-ray microscopic imaging.

The finest X-ray probes have been obtained using zone plates. These are circular diffraction gratings with radially increasing line densities, in a fashion that brings the diffracted $\mathrm{X}$ rays to an axial focus (Folkard et al. 2001a). As with other diffraction devices, several diffracted orders are produced, and the unwanted orders must be prevented from reaching the cells, because they will not be appropriately focused. To do this, an arrangement of masks is used that allows only the first-order diffracted X-rays to reach the target. An important challenge when employing low energy microbeams is the attenuation in air requiring a very delicate dish design (Schettino et al. 2000).

Alongside the self- contained design of these devices, the advantage of electron and X-ray microbeams lies in the ability to easily vary the beam energy and therefore the LET. This enables a range of investigations in the context of relative biological effectiveness (RBE) for different energies. In this respect, electron and X-ray microbeams complement the work done with charged particle facilities to investigate the LET dependence (Folkard et al. 2001b; Wu \& Hei 2017).

Synchrotron microbeams use much higher energies in the range of 2.34-600 keV (Crosbie et al. 2015; Kaminaga et al. 2016). The beamlines use a bending magnet (at low energies) or a wiggler (at higher energies) to produce a virtually parallel beam of X-ray with minimal 
vertical divergence. This is then spatially fractionated using collimators and arranged in an array of alternating parallel micro-planar beams and gaps. This segments the high flux X-ray beam from a synchrotron into a micro-planar lattice of narrow beams, typically $25-50 \mu \mathrm{m}$ wide and with a centre-to-centre separations of 200 or $400 \mu \mathrm{m}$. These can then potentially be cross-fired providing a large array of options for novel treatment modalities (Bouchet et al. 2010; Crosbie et al. 2010). This unique spatial distribution allows the delivery of an array of peak and valley doses. The former is directly deposited in the target by the microbeam while the latter is deposited in the tissue between the beams by scattered photons (Blattmann et al. 2005). The dramatic dose difference between heavily (peaks) and lightly (valleys) irradiated tissue, promoted when a broad beam is converted into an array of microbeams, is a very important characteristic unique to synchrotron microbeams. The peak dose delivered is typically up to 300-800 Gy at skin entry, with valley doses of 12-20 Gy and mean dose rates in the range of thousands Gy s ${ }^{-1}$ (Crosbie et al. 2010; Bräuer-Krisch et al. 2015).

This setup has been used to irradiate cells, tissue and small to medium sized animals in an experimental technique known as MRT, and a schematic representation of a typical MRT dose distribution is shown in figure 2 . This modality was shown to have a preferential killing effect on tumour cells, which has been demonstrated in glioma models (Fernandez-Palomo et al. 2015; Smyth et al. 2016). Hypotheses for the efficacy of MRT suggest it is due to the periodically alternating dose distribution, proposing mechanisms based on observations including the preferential damage to tumour microvasculature compared to normal brain microvasculature in vivo (Bouchet et al. 2010; Bouchet et al. 2016); in-field bystander effects related to cellular migration in vitro and in vivo (Crosbie et al. 2010; Bouchet et al. 2017) and the communication of stress factors in vitro between peak and valley regions (Smyth et al. 2016). Research has also revealed that MRT seems to modulate the immune system by 
regulating the expression of growth factors, cytokines and lymphokines (Bouchet et al. 2013) and the recruitment of tumour-associated immune cells (Yang et al. 2014).

\section{Microbeam dosimetry challenges}

A key feature of modern microbeam facilities is the ability to establish a priori an accurate reproducible dose that will be delivered to each sample. By coupling this with a high efficiency detection system, doses can be precisely monitored and controlled by very fast beam shuttering or deflection system (Melvyn Folkard et al. 1997).

Particle detection characteristics can be used to separate microbeams into two categories based on whether the detection occurs before or after the particles reach the biological sample ( Schettino et al. 2010). By placing the detector between the vacuum window and the sample holder, no further constraints are imposed on the sample holder or the cell environment. However, the inevitable detector-beam interaction reduces the quality and accuracy of the exposure. In order to minimise the energy loss in the detector, only thin, transmission type detectors are appropriate. These detectors are generally thin film plastic scintillators which generate flashes of light when traversed by particles. These flashes are collected by a photomultiplier, and processed into individual particle counts (Melvyn Folkard et al. 1997). An alternative configuration consists of placing the detector behind the sample holder. Using this approach, no extra scattering is introduced by the detector and better targeting accuracy can be reached. While conventional solid state detectors can be used, this configuration requires that the delivered particles have enough energy to pass through the sample, setting a limit on the lowest usable energy. In many cases it is also necessary to remove the culture medium requiring additional procedures to keep cells viable during the irradiation process $(\mathrm{M}$ Folkard et al. 1997) and (Randers-Pehrson et al. 2001). 
Due to the small radiation beam and the localized delivery of the radiation dose, conventional dosimetry approaches are not always relevant for microbeam exposures when used for single cell or sub-cellular targeting. The dosimetry for the microbeam facilities is usually reported in terms of the number of photons/ions delivered to a specific biological target. The delivered dose depends on the particle species, energy along with detector efficiency and geometric characteristics of the cell (Folkard et al. 2001b). The timescale throughout which the radiation is delivered is also an important parameter, particularly for new radiation sources able to deliver high fluxes of radiation.

However, the number of particles (or photons) delivered to the target of interest is only the first dosimetric measurement which has its main advantages in a direct and relatively straightforward comparison of the samples irradiation record. In order to relate the radiation responses measured with microbeams to conventional radiation exposures, it is important to estimate the energy deposited in individual cells or specific sub-cellular targets. Such calculations require the number of radiation events experienced by the cell together with information about the cell geometry and radiation energy. Difficulties in defining the volume (and therefore mass) of interest makes it hard to report such dosimetry assessment in terms of macroscopic dose measurements (i.e. Gy) and has led to definition of parameters such as 'specific dose' which characterises the dose deposited in specific cellular sub-components (Randers-Pehrson 2002).

The dosimetry for synchrotron based microbeams is more complex and requires aspects of spectrum verification (Crosbie et al. 2015) and absolute dose measurements at ultra-high dose rates (Fournier et al. 2016). Standard protocols for high resolution Gafchromic film measurements in combination with microscopy have been used with an accuracy of better than $5 \%$ for the peak dose and between $10 \%$ and $15 \%$ for the valley doses (Bartzsch et al. 2015; Bräuer-Krisch et al. 2015). For MRT, the dose to a large macroscopic volume is 
usually reported together with information about the size of the microbeams, the gap between the microbeams and the ratio of peak-to-valley dose (i.e. dose in the centre of microbeam compared to dose in the gap between the microbeams). Assessment of the dose in such small volumes is challenging and requires dedicated protocols and tools. A variety of detectors have been investigated for dosimetry assessment in synchrotron microbeams with each presenting both limitations and advantages (Bräuer-Krisch et al. 2010), (Alagoz et al. 2016), (Gagliardi et al. 2015), (Okada et al. 2011).

\section{Cellular and tissue effects}

The main focus of research conducted into the effects of ionising radiation on cells has focused on the damage to the cell nucleus and the detrimental effects this has on the cell. Much of radiation biology and radiotherapy builds on the assumption that a high enough dose of energy deposited to the nucleus will ultimately lead to cell death. Within this dogma the cytoplasm, the cellular environment in which most cellular processes take place, has rarely been taken into account. With the development of microbeam facilities, the role of the cytoplasm in radiation-induced biological responses became increasingly important in studies of cytoplasm targeted reactions (Walsh et al. 2017), bystander cellular responses, (Tartier et al. 2007) and in interactions with gold nanoparticles (Ghita et al. 2017).

\section{Subcellular Targeting}

The strength of the micro-irradiation technique lies in its ability to deliver precise doses of radiation to selected individual cells in vitro or to preselected targets within cells. The development of microbeams has allowed further dissection of cellular and molecular events in various experiments for DNA damage and repair (Kashino et al. 2004; Tartier et al. 2007; Richard et al. 2011; Ghita et al. 2017; Walsh et al. 2017). These studies have made use of 
advances in microscopy to quantify the radiation induced stress at different subcellular levels and have made a significant impact on the understanding of mechanistic radiation responses in cells. Also, single cell approaches have also been very useful in establishing the radiation risks related to the crossing of a single and a precise number of $\alpha$ particles (Miller et al. 1999) and (Hei et al. 1997).

Microbeam technology has led the way to further innovation investigating cellular targeting and responses in cells but other approaches have also played a role. For example, studies using Auger electron emitters targeted to different cellular compartments tested their potential to induce non-targeted effects. The induction of these effects was found to be equally potent whether the Auger emitter was located in the cell membrane, in the cytoplasm or in the nucleus of the donor cells (Paillas et al. 2016). Although most of these studies agree on DNA being the most radiosensitive target, other cellular compartments also seem to be involved in both effects, especially the cell membrane (Kassis 2004; Pouget et al. 2008; Kassis 2011; Paillas et al. 2016).

During the past 10 years, there has been a shift away from a totally DNA-centric approach to include models that invoke complex signalling pathways in cells and between cells within tissues. Several newly recognised responses have been classified as so-called non-targeted responses (Tartier et al. 2007) in which biological effects are not directly related to the amount of energy deposited in the DNA of the cells traversed by the radiation.

\section{Intercellular Communication}

A major shift in our thinking about radiation effects has taken place with the finding that nonirradiated cells can respond biologically when their neighbours are irradiated, referred to as bystander responses. The ability to select individual cells or regions of tissues for localized irradiation is key to determining the role of intra- and intercellular signalling, and in depth reviews have been focusing on this aspect for in vitro work (Prise et al. 2010; Prise et al 
1998; G Schettino et al. 2010). The development of single cell microbeams facilitated the evaluation of in vitro oncongenic potential in the bystander cell populations (Sawant et al. 2001). A similar approach was used to analyse the biological response in non-targeted cell populations relative to microbeam irradiated cells (Ponnaiya et al. 2004).

A recent study investigated the cell death and cell-cycle arrest of microbeam-irradiated cells and adjacent non-irradiated bystander cells in a human HeLa-Fucci spheroid culture with time-lapse imaging (Kaminaga et al. 2016). To our knowledge, this was the first real-time imaging of the dynamics of microbeam-irradiated and non-irradiated bystander cells. This was further developed in a study showing radiation-induced pro-inflammatory responses, including signalling in the NF-kB-COX-2 pathway, in a human 3-D organotypic skin culture exposed to modified X-ray fields (Acheva et al 2017).

However, experiments with cell monolayers and single cell irradiation do not take into account the complex cellular responses at the tissue level. Progression to $3 \mathrm{D}$ models can reproduce many of the tissue characteristics in vivo are therefore ideal targets for studying non-targeted effects using microbeams (Durante \& Friedl 2011).

\section{Advanced Tissue Models}

Extending the present two-dimensional (2D) cell culture results to more complex models has been an important area of deyelopment for microbeam research. In recent years, 3D culture methods, such as spheroid cultures (i.e., small aggregates of cells growing free of foreign materials) (Fennema et al. 2013; Ishiguro et al. 2017) and organoid technologies (i.e., stem cell-derived 3-D cultures) (Lancaster \& Knoblich 2014), have been developed to preserve the biological characteristics of the original tissues or organs better than conventional 2D monolayer cultures. This progress could contribute to the elucidation of the molecular mechanisms of radiation-induced bystander responses at the tissue level and has potential for 
the development of new diagnostic and therapeutic radiation techniques (Belyakov et al. 2001; Belyakov et al. 2006), (Buonanno et al. 2015; Peng et al. 2017).

More in vivo-like culture methods, such as ex vivo tissue and organ cultures, also have potential as useful tools for microbeam research. Organotypic tumour tissue slice methods optimized for ex vivo culture would be useful for assessing not only tumour-specific drug responses but also microbeam-induced bystander responses (Vaira et al. 2010; Naipal et al. 2016). Some ex vivo organ culture techniques (e.g., human hair follicle (Langan et al. 2015), mouse testis (Sato et al. 2011)) are likely to be applicable to microbeam research.

Although traditionally hampered by the limited range of particles and photons used, animal models are now also being used in microbeam studies using a single microbeam. So far, these studies focused on very small animals, such as silkworms (Fukamoto et al. 2007) and nematodes (A Bertucci et al. 2009) but can provide important insights on long-range nontargeted effects, beyond the possibility of 3D tissue targets (Durante \& Friedl 2011).

Single microbeam approaches for targeting individual cells offer the possibility to follow the cellular processes in real-time post irradiation. A future advance will be to translate these approaches into in vivo models, particularly to investigate low dose biological consequences. Ideally, these studies need to consider both spatial and temporal responses from cellular $\mathrm{r}$ to functional biological changes (Schettino et al. 2010).

\section{Preclinical applications of MRT}

Finally, moving beyond mechanistic studies, synchrotron MRT has shown high therapeutic potential in small animal models of malignant brain tumours with a preferential effect on intracerebral 9L gliosarcoma vascular networks (Bouchet et al. 2010; Crosbie et al. 2010). In this context a recent study (Fernandez-Palomo et al. 2015) interrogated $\gamma \mathrm{H}_{2} \mathrm{AX}$ as a biomarker for dose deposition in the brain after synchrotron microbeam irradiation. This 
study shows a direct correlation between the irradiation dose and induced foci for entry doses up to 350 Gy. Furthermore, a correlation between the microbeam foci track width and dissection time was observed at the highest dose with no significant change in the width of the microbeam tracks seen at lower irradiation doses. This suggests that radiation induced bystander effects have an impact on the cells exposed to both the high-peak doses and the dose gradient of the transition zone (Fernandez-Palomo, Bräuer-Krisch, et al. 2015).

As a comparison, different DNA damage patterns after irradiation with 2 Gy using C soft Xray of a $2 \mathrm{D}$ monolayer is shown in figure $3 \mathrm{a}$ and $3 \mathrm{~b}$. In an in vivo setup, DNA damage induced after synchrotron irradiation of mouse cerebellum with an entry-dose of $350 \mathrm{~Gy}$ is shown in figure 3c and 3d (Fernandez-Palomo et al. 2015).

\section{Clinical translation for therapy developments}

Microbeam radiation therapy (MRT), an innovative pre-clinical radiotherapy technique using spatially fractionated synchrotron X-rays, has been shown to spare radiosensitive tissues such as mammal brains (Serduc et al. 2008; Bouchet et al. 2016). In MRT the tumour is irradiated by arrays of micrometre wide planar beams of unconventionally high doses of up to a few hundred Gy that are separated by several hundred micrometre wide low dose regions (BräuerKrisch et al. 2005). The major benefit of MRT over conventional radiotherapy approaches is associated with the dose volume effect where the utilization of a micrometre-scale treatment beam width leads to a higher radiation tolerance of normal tissue compared to tumour tissue (Bouchet et al. 2010), (Schültke et al. 2017; Serduc et al. 2008). Pre-clinical studies have demonstrated this advantage in several animal models, such as weanling piglets, duck embryos, and suckling and adult rats (Slatkin et al. 1995; Laissue et al. 1999; Dilmanian et al. 2002; Dilmanian et al. 2003; Dilmanian et al. 2005; Serduc et al. 2009; Van Der Sanden et al. 2010; Laissue et al. 2013; Bouchet et al. 2014). The skin has also been shown to tolerate 
doses of 835-1335 Gy very well in MRT, far above of those used in pre-clinical studies (350 Gy) (Zhong et al. 2003). Moreover, the acute effects on skin produced by high MRT doses were similar to the effects of low doses of broad beam (Priyadarshika et al. 2011). Thus, the organ tolerance, particularly of the normal brain, could allow re-irradiation of the tumour.

MRT in small animal models has achieved therapeutic ratios clearly exceeding those obtained by homogeneous dose distributions delivered using conformal preclinical radiotherapy in a range of malignancies (Grotzer et al. 2015). Currently, the production of clinical microbeams can only be facilitated at large synchrotron facilities like the European Synchrotron (ESRF) in Grenoble and the Imaging and Medical Beamline (IMBL) at the Australian Synchrotron, due to the high beam flux and quality requirements. However, the possibility to use a conventional X-ray tube or carbon nanotubes (S. Wang et al. 2011) to produce microbeams for preclinical studies has also been explored. This study used an X-ray tube with a small focal spot and a specially designed collimator were used to produce microbeams for preclinical research (Bartzsch et al. 2016).

The growing interest in bright monochromatic and tuneable X-ray sources for use in imaging and radiation therapy has led to the collaboration of seven research institutes and industry partners in the ThomX project, to develop a compact Compton Backscattering Source (CBS) based in Orsay - France (Variola et al. 2014). The project aims to provide a fully operational hard X-ray CBS upgradable to be operated with a relatively reduced cost (Alagoz et al. 2016). Another recent study proposes another novel technical solution of line focus X-ray tubes, with the aim of clinical translation of MRT (Bartzsch \& Oelfke 2017). Long term, this might enable the development of clinical microbeams without the need of a synchrotron.

Various biological mechanisms have been suggested to explain MRT's effectiveness. Strong evidence indicating that the different repair efficiencies of blood vessels in malignant and 
healthy tissue is a key factor in explaining the differential effect of microbeams (Bouchet et al. 2010).

Given the clinical potential of MRT, robust normal tissue toxicity data, especially pre-clinical depth-dose data, must be collected in order to successfully translate these therapies to human clinical trials. While previous work employed computational modelling (Merrem et al. 2017), a lack of robust reference data means that further experimental studies on the geometric properties of vascular networks are necessary to improve the predictions of the model. Previous reviews summarized the available normal tissue toxicity data from MRT animal studies and have considered how they relate to current normal tissue toxicity data and clinical dose constraints (Smyth et al. 2016). Furthermore, a novel treatment planning environment for synchrotron MRT has been developed based on the Eclipse ${ }^{\mathrm{TM}}$ treatment planning system (Poole et al. 2017). This is an essential step in MRT progression towards human clinical trials, as it is necessary that MRT not only meets current clinical standards but also has similarity with all stages of the radiotherapy process (Grotzer et al. 2015).

As part of the development of a clinical case for MRT, candidate populations for potential clinical trials have been discussed. Two key sites, in adults with glioblastoma multiforme and in paediatric patients with diffuse intrinsic pontine glioma, have been identified (Grotzer et al. 2015).

The phase 1 clinical trials in Synchrotron Stereotactic Radiotherapy (SSRT) have allowed the community to move forward with synchrotron based therapies requiring the implementation of a small hospital like environment at the biomedical beamline ID17 at the ESRF. With the SSRT clinical trial it will be possible to refine a protocol for dose enhancement using high Z elements in combination with low energy synchrotron X-rays. This can also be further exploited to improve the tumour control probability (TCP) in MRT (Bräuer-Krisch et al. 2015; Grotzer et al. 2015). 


\section{Summary and future directions}

Microbeams have played a pivotal role in radiobiology. In its early days, the technology aimed to explore basic radiobiological effects after cellular irradiation. With the ongoing evolution of the field, microbeams have been refined to assess a range of responses after irradiation with X-ray or charged particles. The main advantage of the technology, the very controlled irradiation of micron-sized areas of tissue, has initiated novel research avenues beyond the investigation of the underlying mechanisms of radiotherapy. Microbeam technology has also served as the underpinning for MRT - a technique with the potential to impact the clinical landscape. Since the first reports using very small targeted radiation beams, the theoretical possibility of radiosurgery by irradiating parallel arrays of micro slices and cross-fired through tumours from several ports has attracted the attention of several groups internationally.

While the MRT concept has also been extended to proton heavy ion therapies, the development towards its clinical implementation is still a focus of radiation therapy programmes aiming towards its integration in the hospital environment (Bravin et al. 2015). With the increased number of potential applications of these technologies, novel technical and medical physics developments are key to further implement these methods into a clinical environment.

\section{Acknowledgements}

H.F. is funded by a fellowship from the International Exchange and Research Grant of Marubun Research Promotion Foundation, Japan. 
KTB and KMP would like to acknowledge the UK Department of Health (091/0205) for supporting their work.

EBK and all authors want to acknowledge Prof. Jean Laissue for his vital contribution in the field of MRT.

\section{Disclosure Statement}

The authors report no conflict of interest.

\section{Biographical Notes}

Dr. Mihaela Ghita is a Postdoctoral Research Assistant at Centre for Cancer Research and Cell Biology (CCRCB), in the Radiation Biology group led by Prof. Prise. Her research focuses on in vitro and in vivo studies of targeted and non-targeted radiation induced effects aiming to enable the fine tuning of preclinical models to the specific tumour biology.

Dr. Cristian Fernandez-Palomo is a Postdoctoral Fellow at University of Bern and studies the effects of Synchrotron radiation to improve the treatment of skin cancer using spatially fractionated microbeams to increase the normal tissue tolerance to the radiotherapy treatment.

Hisanori Fukunaga is a PhD student in the Radiation Biology Group within the CCRCB led by prof. Prise. His research focuses on Radiobiological Implications of the Fukushima nuclear accident and radiation-induced effects on spermatogenesis.

Dr. Pil M. Fredericia is a Postdoctoral Fellow at Technical University of Denmark, Institute for Nuclear Technologies. Her work is focusing on quantification of radiation induced DNA damage following intracellular Auger cascade

Dr. Giuseppe Schettino is Principal Research Scientist in the Radiation Dosimetry Group at the NPL. His main research interest is in radiation biology, advanced radiotherapy and 
dosimetry. He is leading UK initiatives for standardization of dosimetry and QA processes for pre-clinical radiotherapy and radiobiology research.

Dr. Karl T. Butterworth is a Lecturer in Translational Radiation Biology in the Advanced Radiotherapy Group within the CCRCB. His research group is focussed on translational studies using in vivo models for preclinical radiotherapy and imaging. His work focuses on developing novel radiation based strategies to overcome radioresistance and minimise toxicities in normal tissues.

Dr. Elke Brauer Krisch is the Project Leader for Microbeam Radiation Therapy (MRT) at European Synchrotron Radiation Facility, Direction of Experiments. Her research interests are focussed on in vivo effects as well as dosimetric aspects of MRT.

Dr. Stephen McMahon is a Queen's Research Fellow within the CCRCB. His work focuses on the development of predictive models of radiation response, taking into account factors such as irradiation geometry, radiation quality, and intrinsic cellular radiosensitivity.

Prof. Kevin M. Prise is Deputy Director of CCRCB, Professor of Radiation Biology and Head of the Radiation Biology Group at Queen's University Belfast. His research group is multidisciplinary with strong expertise in both radiation physics and radiation biology and is working in areas related to both radiation protection and radiotherapy 


\section{References:}

A Bertucci, R D. J. Pocock, Randers-Pehrson G, D J. Brenner. 2009. Microbeam Irradiation of the C. elegans Nematode. J Radiat Res. 50:49-54.

Acheva A, Schettino G, Prise KM. 2017. Pro-inflammatory Signaling in a 3D Organotypic Skin Model after Low LET Irradiation-NF-אB, COX-2 Activation, and Impact on Cell Differentiation. Front Immunol. 8:82.

Alagoz E, Brauer-Krisch E, Bravin A, Cornelius I, Fournier P, Hansen TE, Kok A, Lerch M, Monakhov E, Morse J, et al. 2016. Multi-strip silicon sensors for beam array monitoring in microbeam radiation therapy. Phys Medica. 32:1795-1800.

Barberet P, Seznec H. 2015. Advances in Microbeam Technologies and Applications To Radiation Biology. 166:182-187.

Bartzsch S, Cummings C, Eismann S, Oelfke U. 2016. A preclinical microbeam facility with a conventional x-ray tube. Med Phys . 43:6301-6308.

Bartzsch S, Lott J, Welsch K, Bräuer-Krisch E, Oelfke U. 2015. Micrometer-resolved film dosimetry using a microscope in microbeam radiation therapy. Med Phys. 42:4069-4079.

Bartzsch S, Oelfke U. 2017. Line focus x-ray tubes - a new concept to produce high brilliance X-rays. Phys Med Biol.

Belyakov O V., Folkard M, Mothersill C, Prise KM, Michael BD. 2006. Bystander-induced differentiation: A major response to targeted irradiation of a urothelial explant model. Mutat Res Fundam Mol Mech Mutagen. 597:43-49.

Belyakov O V, Malcolmson AM, Folkard M, Prise KM, Michael BD. 2001. Direct evidence for a bystander effect of ionizing radiation in primary human fibroblasts. Br J Cancer. 84:674-679.

Blattmann H, Gebbers J-O, Bräuer-Krisch E, Bravin A, Le Duc G, Burkard W, Di Michiel M, Djonov V, Slatkin DN, Stepanek J, Laissue J a. 2005. Applications of synchrotron X-rays to radiotherapy. Nucl Instruments Methods Phys Res Sect A Accel Spectrometers, Detect Assoc Equip. 548:17-22.

Bouchet A, Bidart M, Miladi I, Le Clec'h C, Serduc R, Coutton C, Regnard P, Khalil E, Dufort S, Lemasson B, et al. 2014. Characterization of the $9 \mathrm{~L}$ gliosarcoma implanted in the Fischer rat: an orthotopic model for a grade IV brain tumor. Tumour Biol. 35:6221-33.

Bouchet A, Bräuer-Krisch E, Prezado Y, El Atifi M, Rogalev L, Le Clec'h C, Laissue JA, Pelletier L, Le Duc G. 2016. Better Efficacy of Synchrotron Spatially Microfractionated Radiation Therapy Than Uniform Radiation Therapy on Glioma. Int J Radiat Oncol Biol Phys. 95:1485-1494.

Bouchet A, Lemasson B, Le Duc G, Maisin C, Bräuer-Krisch E, Siegbahn EA, Renaud L, Khalil E, Rémy C, Poillot C, et al. 2010. Preferential effect of synchrotron microbeam radiation therapy on intracerebral 91 gliosarcoma vascular networks. Int J Radiat Oncol Biol Phys. 78:1503-1512.

Bouchet A, Potez M, Coquery N, Rome C, Lemasson B, Bräuer-Krisch E, Rémy C, Laissue J, Barbier EL, Djonov V, Serduc R. 2017. Permeability of Brain Tumor Vessels Induced by Uniform or Spatially Microfractionated Synchrotron Radiation Therapies. Int J Radiat Oncol Biol Phys. 98:11741182.

Bouchet A, Sakakini N, El Atifi M, Le Clec'h C, Brauer E, Moisan A, Deman P, Rihet P, Le Duc G, Pelletier L. 2013. Early gene expression analysis in 9L orthotopic tumor-bearing rats identifies immune modulation in molecular response to synchrotron microbeam radiation therapy. PLoS One. 8:e81874.

Bourret S, Vianna F, Devès G, Atallah V, Moretto P, Seznec H, Barberet P. 2014. Fluorescence timelapse imaging of single cells targeted with a focused scanning charged-particle microbeam. Nucl 
Instruments Methods Phys Res Sect B Beam Interact with Mater Atoms. 325:27-34.

Braby LA. 1991. Microbeam studies of the sensitivity of structures within living cells. Scanning Microsc Meet Bethesda,. MD (USA).

Bräuer-Krisch E, Adam JF, Alagoz E, Bartzsch S, Crosbie J, DeWagter C, Dipuglia A, Donzelli M, Doran S, Fournier P, et al. 2015. Medical physics aspects of the synchrotron radiation therapies: Microbeam radiation therapy (MRT) and synchrotron stereotactic radiotherapy (SSRT). Phys Medica. 31:568-583.

Bräuer-Krisch E, Requardt H, Brochard T, Berruyer G, Renier M, Laissue JA, Bravin A. 2009. New technology enables high precision multislit collimators for microbeam radiation therapy. Rev Sci Instrum. 80 .

Bräuer-Krisch E, Requardt H, Régnard P, Corde S, Siegbahn E, LeDuc G, Brochard T, Blattmann H, Laissue J, Bravin a. 2005. New irradiation geometry for microbeam radiation therapy. Phys Med Biol. 50:3103-11.

Bräuer-Krisch E, Rosenfeld A, Lerch M, Petasecca M, Akselrod M, Sykora J, Bartz J, Ptaszkiewicz M, Olko P, Berg A, et al. 2010. Potential high resolution dosimeters for MRT. AIP Conf Proc. 1266:89-97.

Bravin A, Olko P, Schültke E, Wilkens JJ. 2015. SYRA3 COST Action - Microbeam radiation therapy: Roots and prospects. Phys Medica. 31:561-563.

Buonanno M, Randers-Pehrson G, Smilenov LB, Kleiman NJ, Young E, Ponnayia B, Brenner DJ. 2015. A Mouse Ear Model for Bystander Studies Induced by Microbeam Irradiation. Radiat Res. 184:219-225.

Butz T, Flagmeyer RH, Heitmann J, Jamieson DN, Legge GJF, Lehmann D, Reibetanz U, Reinert T, Saint A, Spemann D, et al. 2000. The Leipzig high-energy ion nanoprobe: A report on first results. Nucl Instruments Methods Phys Res Sect B Beam Interact with Mater Atoms. 161:323-327. 8

Clement CH, Stewart FA, Akleyev A V., Hauer-Jensen M, Hendry JH, Kleiman NJ, Macvittie TJ, Aleman BM, Edgar AB, Mabuchi K, et al. 2012. ICRP Statement on Tissue Reactions and Early and Late Effects of Radiation in Normal Tissues and Organs - Threshold Doses for Tissue Reactions in a Radiation Protection Context. Ann ICRP. 41:1-322.

Crosbie JC, Anderson RL, Rothkamm K, Restall CM, Cann L, Ruwanpura S, Meachem S, Yagi N, Svalbe I, Lewis RA, et al. 2010. Tumor Cell Response to Synchrotron Microbeam Radiation Therapy Differs Markedly From Cells in Normal Tissues. Int J Radiat Oncol Biol Phys. 77:886-894.

Crosbie JC, Fournier P, Bartzsch S, Donzelli M, Cornelius I, Stevenson AW, Requardt H, BräuerKrisch E. 2015. Energy spectra considerations for synchrotron radiotherapy trials on the ID17 biomedical beamline at the European Synchrotron Radiation Facility. J Synchrotron Radiat. 22:10351041.

D. T. Goodhead. 1994. Initial Events in the Cellular Effects of Ionizing Radiations: Clustered Damage in DNA. Int J Radiat Biol. 65.

Dilmanian F a, Qu Y, Liu S, Cool CD, Gilbert J, Hainfeld JF, Kruse C a, Laterra J, Lenihan D, Nawrocky MM, et al. 2005. X-ray microbeams: Tumor therapy and central nervous system research. Nucl Instrum Methods Phys Res A. 548:30-37.

Dilmanian FA, Button TM, Le Duc G, Zhong N, Peña LA, Smith JAL, Martinez SR, Bacarian T, Tammam J, Ren B. 2002. Response of rat intracranial 9L gliosarcoma to microbeam radiation therapy. Neuro Oncol. 4:26.

Dilmanian FA, Morris GM, Zhong N, Bacarian T, Hainfeld JF, Kalef-Ezra J, Brewington LJ, Tammam J, Rosen EM. 2003. Murine EMT-6 carcinoma: high therapeutic efficacy of microbeam 
radiation therapy. Radiat Res. 159:632-41.

Dollinger G, Hable V, Hauptner A, Krücken R, Reichart P, Friedl AA, Drexler G, Cremer T, Dietzel S. 2005. Microirradiation of cells with energetic heavy ions. Nucl Instruments Methods Phys Res Sect B Beam Interact with Mater Atoms. 231:195-201.

Drexler GA, Ruiz-Gómez MJ. 2015. Microirradiation techniques in radiobiological research. J Biosci. 40:629-643.

Durante M, Friedl AA. 2011. New challenges in radiobiology research with microbeams. Radiat Env Biophys. 50:335-338.

Fennema E, Rivron N, Rouwkema J, van Blitterswijk C, de Boer J. 2013. Spheroid culture as a tool for creating 3D complex tissues. Trends Biotechnol. 31:108-15.

Fernandez-Palomo C, Bräuer-Krisch E, Laissue J, Vukmirovic D, Blattmann H, Seymour C, Schültke E, Mothersill C. 2015. Use of synchrotron medical microbeam irradiation to investigate radiationinduced bystander and abscopal effects in vivo. Phys Medica. 31:584-595.

Fernandez-Palomo C, Mothersill C, Br?uer-Krisch E, Laissue J, Seymour C, Sch?ltke E. 2015. ?$\mathrm{H} 2 \mathrm{AX}$ as a marker for dose deposition in the brain of wistar rats after synchrotron microbeam radiation. PLoS One. 10:1-17.

Folkard M, Schettino G, Vojnovic B, Gilchrist S, Michette a G, Pfauntsch SJ, Prise KM, Michael BD. 2001a. A focused ultrasoft $\mathrm{x}$-ray microbeam for targeting cells individually with submicrometer accuracy. Radiat Res. 156:796-804.

Folkard M, Schettino G, Vojnovic B, Gilchrist S, Michette a G, Pfauntsch SJ, Prise KM, Michael BD. 2001b. A focused ultrasoft $\mathrm{x}$-ray microbeam for targeting cells individually with submicrometer accuracy. Radiat Res. 156:796-804.

Folkard M, Vojnovic B, Hollis KJ, Bowey AG, Watts SJ, Prise KM, Michael BD. 1997. A chargedparticle microbeam : II . A single-particle micro-collimation and detection system . Int J Radiat Biol. 72:387-395.

Folkard M, Vojnovic B, Schettino G, Forsberg M, Bowey G, Prise KM, Michael BD, Michette AG, Pfauntsch SJ. 1997. Two approaches for irradiating cells individually: a charged-panicle microgram and a soft X-ray microprobe. Nucl Instruments Methods Phys Res B. 130:270-273.

Fournier P, Crosbie JC, Cornelius I, Berkvens P, Donzelli M, Clavel AH, Rosenfeld AB, Petasecca M, Lerch MLF, Bräuer-Krisch E. 2016. Absorbed dose-to-water protocol applied to synchrotrongenerated x-rays at very high dose rates. Phys Med Biol. 61:N349-61.

Fukamoto K, Shirai K, Sakata T, Sakashita T, Funayama T, Hamada N, Wada S, Kakizaki T, Shimura S, Kobayashi Y, et al. 2007. Development of the Irradiation Method for the First Instar Silkworm Larvae Using Locally Targeted Heavy-ion Microbeam. 48:247-253.

Funayama T, Wada S, Kobayashi Y, Watanabe H. 2005. Irradiation of mammalian cultured cells with a collimated heavy-ion microbeam. Radiat Res. 163:241-246.

Gagliardi FM, Cornelius I, Blencowe A, Franich RD, Geso M. 2015. High resolution 3D imaging of synchrotron generated microbeams. Med Phys. 42:6973.

Ghita M, McMahon SJ, Taggart LE, Butterworth KT, Schettino G, Prise KM. 2017. A mechanistic study of gold nanoparticle radiosensitisation using targeted microbeam irradiation. Sci Rep. 7:44752.

Grotzer MA, Schültke E, Bräuer-Krisch E, Laissue JA. 2015. Microbeam radiation therapy: Clinical perspectives. Phys Medica. 31:564-567.

Harken AD, Randers-Pehrson G, Johnson GW, Brenner DJ. 2011. The Columbia University protoninduced soft X-ray microbeam. Nucl Instruments Methods Phys Res Sect B Beam Interact with Mater 
Atoms. 269:1992-1996.

Hei TK, Wu LJ, Liu X, Vannais D, Waldren CA, Rander-Pehrsen G. 1997. Mutagenic effects of a single and an exact number of $\smile$ particles in mammalian cells. Proc Natl Acad Sci USA. 94:37653770 .

Heiss M, Fischer BE, Jakob B, Fournier C, Becker G, Taucher-Scholz G. 2006. Targeted irradiation of Mammalian cells using a heavy-ion microprobe. Radiat Res. 165:231-9.

Ishiguro T, Ohata H, Sato A, Yamawaki K, Enomoto T, Okamoto K. 2017. Tumor-derived spheroids: Relevance to cancer stem cells and clinical applications. Cancer Sci. 108:283-9.

Iwai Y, Ikeda T, Kojima TM, Yamazaki Y, Maeshima K, Imamoto N, Kobayashi T, Nebiki T, Narusawa T, Pokhil GP. 2008. Ion irradiation in liquid of $\mu \mathrm{m} 3$ region for cell surgery. Appl Phys Lett. 92:1-4.

Joiner M, van der Kogel A. 2009. Basic clinical Radiobiology. Fourth edi. Joiner M, van der Kogel A, editors. London: Hodder Education, Hachette UK.

Kaminaga K, Noguchi M, Narita A, Hattori Y, Usami N, Yokoya A. 2016. Cell cycle tracking for irradiated and unirradiated bystander cells in a single colony with exposure to a soft X-ray microbeam. Int J Radiat Biol. 92:739-744.

Kashino G, Prise KM, Schettino G, Folkard M, Vojnovic B, Michael BD, Suzuki K, Kodama S, Watanabe M. 2004. Evidence for induction of DNA double strand breaks in the bystander response to targeted soft X-rays in CHO cells. Mutat Res - Fundam Mol Mech Mutagen. 556:209-215.

Kassis AI. 2004. The amazing world of Auger electrons. Int J Radiat Biol. 80:789-803.

Kassis AI. 2011. Molecular and cellular radiobiological effects of Auger emitting radionuclides. Radiat Prot Dosimetry. 143:241-247.

Konishi T, Oikawa M, Suya N, Ishikawa T, Maeda T, Kobayashi A, Shiomi N, Kodama K, Hamano T, Homma-Takeda S, et al. 2013. SPICE-NIRS microbeam: a focused vertical system for proton irradiation of a single cell for radiobiological research. J Radiat Res. 54:736-47.

Laissue J a, Bartzsch S, Blattmann H, Bräuer-Krisch E, Bravin A, Dalléry D, Djonov V, Hanson AL, Hopewell JW, Kaser-Hotz B, et al. 2013. Response of the rat spinal cord to X-ray microbeams. Radiother Oncol. 106:106-11.

Laissue JA, Lyubimova N, Wagner H-P, Archer DW, Slatkin DN, Di Michiel M, Nemoz C, Renier M, Brauer E, Spanne PO, et al. 1999. Microbeam radiation therapy. In: Barber HB, Roehrig H, editors. SPIE's Int Symp Opt Sci Eng Instrum. [place unknown]: International Society for Optics and Photonics; p. 38-45.

Lancaster MA, Knoblich JA. 2014. Organogenesis in a dish: modeling development and disease using organoid technologies. Science (80- ). 345:1247125.

Langan EA, Philpott MP, Kloepper JE, Paus R. 2015. Human hair follicle organ culture: theory, application and perspectives. Exp Dermatol. 24:903-11.

Merchant MJ, Jeynes JCG, Grime GW, Palitsin V, Tullis IDW, Barber PR, Vojnovic B, Webb RP, Kirkby KJ. 2012. A focused scanning vertical beam for charged particle irradiation of living cells with single counted particles. Radiat Res. 178:182-90.

Merrem A, Bartzsch S, Laissue JA, Oelfke U. 2017. Computational modelling of the cerebral cortical microvasculature: effect of x-ray microbeams versus broad beam irradiation. Phys Med Biol. 62:3902-3922.

Miller RC, Randers-Pehrson G, Geard CR, Hall EJ, Brenner DJ. 1999. The oncogenic transforming potential of the passage of single particles through mammalian cell nuclei. Proc Natl Acad Sci. 96:19- 
Mosconi M, Giesen U, Langner F, Mielke C, Dalla Rosa I, Dirks WG. 2011. 53BP1 and MDC1 foci formation in HT-1080 cells for low- and high-LET microbeam irradiations. Radiat Environ Biophys. $50: 345-352$.

Naipal KAT, Verkaik NS, Sánchez H, van Deurzen CHM, den Bakker MA, Hoeijmakers JHJ, Kanaar R, Vreeswijk MPG, Jager A, van Gent DC. 2016. Tumor slice culture system to assess drug response of primary breast cancer. BMC Cancer. 16:78.

Okada G, Morrell B, Koughia C, Edgar A, Varoy C, Belev G, Wysokinski T, Chapman D, Kasap S. 2011. Spatially resolved measurement of high doses in microbeam radiation therapy using samarium doped fluorophosphate glasses. Appl Phys Lett. 99.

Paillas S, Ladjohounlou R, Lozza C, Pichard A, Boudousq V, Jarlier M, Sevestre S, Le Blay M, Deshayes E, Sosabowski J, et al. 2016. Localized Irradiation of Cell Membrane by Auger Electrons Is Cytotoxic Through Oxidative Stress-Mediated Nontargeted Effects. Antioxid Redox Signal. 25:467484.

Patrono C, Monteiro Gil O, Giesen U, Langner F, Pinto M, Rabus H, Testa A. 2015. "BioQuaRT" project: Design of a novel In Situ protocol for the simultaneous visualisation of chromosomal aberrations and micronuclei after irradiation at microbeam facilities. Radiat Prot Dosimetry. 166:197199.

Peng Y, Zhang M, Zheng L, Liang Q, Li H, Chen J-T, Guo H, Yoshina S, Chen Y-Z, Zhao X, et al. 2017. Cysteine protease cathepsin B mediates radiation-induced bystander effects. Nature. 547:458462.

Ponnaiya B, Jenkins-baker G, Brenner DJ, Hall EJ, Randers-pehrson G, Geard CR. 2004. Biological Responses in Known Bystander Cells Relative to Known Microbeam-Irradiated Cells. 432:426-432.

Poole CM, Day LRJ, Rogers PAW, Crosbie JC. 2017. Synchrotron microbeam radiotherapy in a commercially available treatment planning system. Biomed Phys Eng Express. 3:25001.

Pouget J-P, Santoro L, Raymond L, Chouin N, Bardiès M, Bascoul-Mollevi C, Huguet H, Azria D, Kotzki P-O, Pèlegrin M, et al. 2008. Cell membrane is a more sensitive target than cytoplasm to dense ionization produced by auger electrons. Radiat Res. 170:192-200.

Prise KM, Schettino G, Vojnovic B, Belyakov O. 2010. Europe PMC Funders Group Microbeam Studies of the Bystander Response. 50:1-8.

Prise KM, Belyakov OV, Folkard M MB. 1998. Studies of bystander effects in human fibroblasts using a charged particle microbeam. Int J Radiat Biol. 74:793-8.

Priyadarshika RCU, Crosbie JC, Kumar B, Rogers P a W. 2011. Biodosimetric quantification of short-term synchrotron microbeam versus broad-beam radiation damage to mouse skin using a dermatopathological scoring system. Br J Radiol. 84:833-42.

Randers-Pehrson G. 2002. Microbeams, microdosimetry and specific dose. Radiat Prot Dosimetry. 99:471-2.

Randers-Pehrson G, Geard CR, Johnson G, Elliston CD, Brenner DJ. 2001. The Columbia University Single-Ion Microbeam. 214:210-214.

Richard DJ, Savage K, Bolderson E, Cubeddu L, So S, Ghita M, Chen DJ, White MF, Richard K, Prise KM, et al. 2011. HSSB1 rapidly binds at the sites of DNA double-strand breaks and is required for the efficient recruitment of the MRN complex. Nucleic Acids Res. 39:1692-1702.

Van Der Sanden B, Bräuer-Krisch E, Siegbahn EA, Ricard C, Vial JC, Laissue J. 2010. Tolerance of arteries to microplanar X-ray beams. Int J Radiat Oncol Biol Phys. 77:1545-1552. 
Sato T, Katagiri K, Gohbara A, Inoue K, Ogonuki N, Ogura A, Kubota Y, Ogawa T. 2011. In vitro production of functional sperm in cultured neonatal mouse testes. Nature. 471:504-7.

Sawant SG, Geard CR, Brenner DJ, Hall EJ, Bystander EJT. 2001. The Bystander Effect in Radiation Oncogenesis : I . Transformation in $\mathrm{C} 3 \mathrm{H} 10 \mathrm{~T} 1 / 2$ Cells In Vitro can be Initiated in the Unirradiated Neighbors of Irradiated Cells. 401:397-401.

Schettino G, Folkard M, Prise KM, Vojnovic B, English T, Michette AG, Pfauntsch JS, Forsberg M, Michael BD. 1997. The soft X-ray microprobe: A fine sub-cellular probe for investigating the spatial aspects of the interaction of ionizing radiations with tissue. Spec Publ R Soc Chem. 204:347-352.

Schettino G, Folkard M, Vojnovic B, Michette A, Prise KM, Electromagnet A. 2010. X-ray Microbeams for Radiobiological Studies: Current Status and Future Challenges. Piers 2010 Xi'an Prog Electromagn Res Symp Proceedings, Vols 1 2.:56-60.

Schettino G, Folkard M, Vojnovic B, Michette AG, Stekel D, Pfauntsch SJ, Prise KM, B.D. Michael. 2000. The ultrasoft X-ray microbeam: a subcellular probe of radiation response. Radiat Res. 153:223225.

Schettino G, Al Rashid S, Prise K. 2010. NIH Public Access. Mutat Res. 704:68-77.

Schültke E, Balosso J, Breslin T. 2017. Microbeam radiation therapy — grid therapy and beyond : a clinical perspective.

Serduc R, Bouchet A, Bräuer-Krisch E, Laissue JA, Spiga J, Sarun S, Bravin A, Fonta C, Renaud L, Boutonnat J, et al. 2009. Synchrotron microbeam radiation therapy for rat brain tumor palliationinfluence of the microbeam width at constant valley dose. Phys Med Biol. 54:6711-24.

Serduc R, van de Looij Y, Francony G, Verdonck O, van der Sanden B, Laissue J, Farion R, BräuerKrisch E, Siegbahn EA, Bravin A, et al. 2008. Characterization and quantification of cerebral edema induced by synchrotron x-ray microbeam radiation therapy. Phys Med Biol. 53:1153-1166.

Siragusa M, Baiocco G, Fredericia PM, Friedland W, Groesser T, Ottolenghi A, Jensen M. 2017. The COOLER Code: A Novel Analytical Approach to Calculate Subcellular Energy Deposition by Internal Electron Emitters. Radiat Res. 188:204-220.

Slatkin DN, Spanne P, Dilmanian F a, Gebbers JO, Laissue JA. 1995. Subacute neuropathological effects of microplanar beams of x-rays from a synchrotron wiggler. Proc Natl Acad Sci U S A. 92:8783-8787.

Slatkin D N, Spanne F, Dilmanian FA, Sandborg M. 1992. Microbeam radiation therapy. Med Phys. 19:1395-1400.

Smyth LML, Senthi S, Crosbie JC, Rogers P a. W. 2016. The normal tissue effects of microbeam radiotherapy: What do we know, and what do we need to know to plan a human clinical trial? Int $\mathrm{J}$ Radiat Biol. 3002:1-10.

Sowa MB, Murphy MK, Miller JH, McDonald JC, Strom DJ, Kimmel GA. 2005. A variable-energy electron microbeam: a unique modality for targeted low-LET radiation. Radiat Res. 164:695-700.

Tartier L, Gilchrist S, Burdak-Rothkamm S, Folkard M, Prise KM. 2007. Cytoplasmic irradiation induces mitochondrial-dependent 53BP1 protein relocalization in irradiated and bystander cells. Cancer Res. 67:5872-5879.

Vaira V, Fedele G, Pyne S, Fasoli E, Zadra G, Bailey D, Snyder E, Faversani A, Coggi G, Flavin R, et al. 2010. Preclinical model of organotypic culture for pharmacodynamic profiling of human tumors. Proc Natl Acad Sci U S A. 107:8352-6.

Variola A, Auguste D, Blin A, Bonis J, Bouaziz S, Bruni C, Cassou K, Chaikovska I, Chancé S, Chaumat V, et al. 2014. The ThomX project status. IPAC 2014 Proc 5th Int Part Accel Conf. WEPRO052:2062-2064. 
W Z, HJ C, EL G, Haymaker. 1959. Tolerance of Mouse-Brain Tissue to High-Energy Deuterons. Science (80- ). 130:0-2.

Walsh DWM, Siebenwirth C, Greubel C, Ilicic K, Reindl J, Girst S, Muggiolu G, Simon M, Barberet P, Seznec H, et al. 2017. Live cell imaging of mitochondria following targeted irradiation in situ reveals rapid and highly localized loss of membrane potential. Sci Rep. 7:46684.

Wang S, Calderon X, Peng R, Schreiber EC, Zhou O, Chang S. 2011. A carbon nanotube field emission multipixel x-ray array source for microradiotherapy application. Appl Phys Lett. 98:1-4.

Wang XF, Li JQ, Wang JZ, Zhang JX, Liu A, He ZJ, Zhang W, Zhang B, Shao CL, Shi LQ. 2011. Current progress of the biological single-ion microbeam at FUDAN. Radiat Environ Biophys. 50:353-364.

Wu J, Hei TK. 2017. Focus small to find big - the microbeam story. Int J Radiat Biol. 0:1-7.

Yang Y, Crosbie JC, Paiva P, Ibahim M, Stevenson A, Rogers P a. W. 2014. In Vitro Study of Genes and Molecular Pathways Differentially Regulated by Synchrotron Microbeam Radiotherapy. Radiat Res. 182:626-639.

Zhong N, Morris GM, Bacarian T, Rosen EM, Avraham Dilmanian F. 2003. Response of Rat Skin to High-Dose Unidirectional X-Ray Microbeams: A Histological Study. Radiat Res. 160:133-142.

Zirkle, Raymond E, William B. 1953. Irradiation of Parts of Individual Cells. Science (80- ). Vol. 117:487-493.

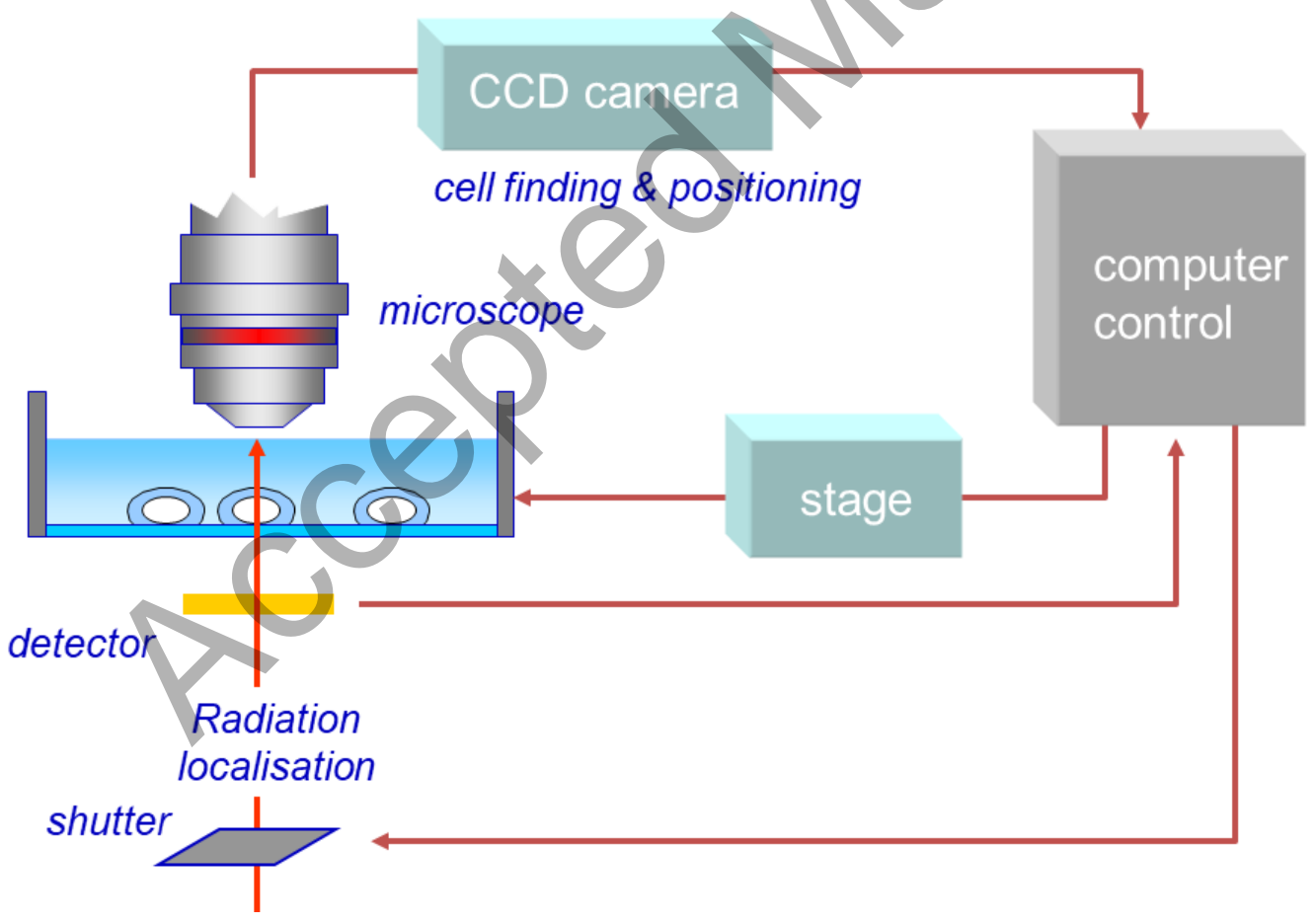

Figure 1 Key accessories for a single cell irradiation a microbeam 


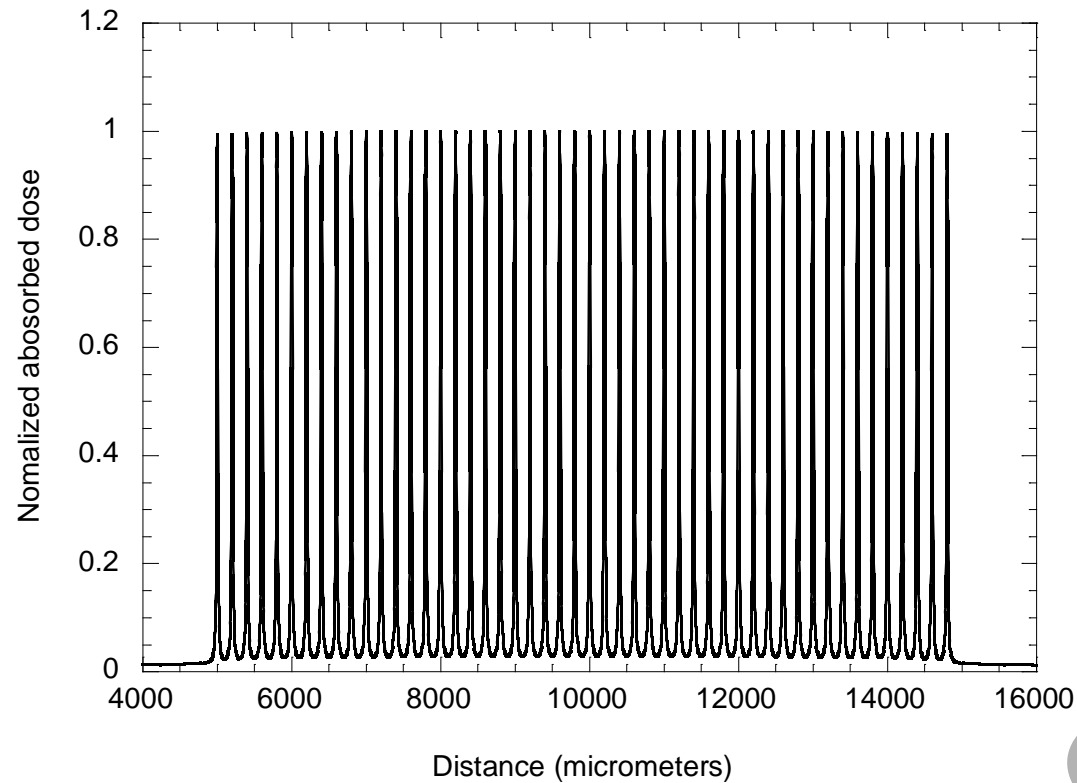

Figure 2 Calculated lateral normalized dose profile for classical microbeam irradiation showing very steep dose gradients between peak doses and low doses delivered in the dose-valley regions. 
Table 1 Updated list of particle microbeam facilities after (Barberet \& Seznec 2015)

\begin{tabular}{|c|c|c|c|}
\hline Facility & Particle & Energy Range & Reference \\
\hline $\begin{array}{l}\text { RARAF Columbia } \\
\text { University }\end{array}$ & Protons, $\alpha$ & 1-5 MeV & $\begin{array}{l}\text { Randers-Pehrson et al } 1996 \\
\text { (Buonanno et al. 2015) }\end{array}$ \\
\hline SPICE NIRS Chiba & Protons & $3.4 \mathrm{MeV}$ & $\begin{array}{l}\text { Konishi et al } 2013 \text { (Konishi et } \\
\text { al. 2013) }\end{array}$ \\
\hline Ion Beam Centre Surrey & Protons, $\alpha$, up to $\mathrm{Ca}$ & 1-12 MeV & $\begin{array}{l}\text { Merchant et al } 2012 \\
\text { (Merchant et al. 2012) }\end{array}$ \\
\hline IMP Fudan & Protons, $\alpha$ & $6 \mathrm{MeV}$ & $\begin{array}{l}\text { Wang et al } 2011 \text { (X.F. Wang et } \\
\text { al. 2011) }\end{array}$ \\
\hline CENBG Bordeaux & Protons, $\alpha$ & $1-3.5 \mathrm{MeV}$ & Bourret et al 2014 (Bourret et \\
\hline PTB Braunschweig & Protons, $\alpha$ & $2-20 N$ & $\begin{array}{l}\text { Mosconi et al } 2011 \text { (Mosconi } \\
\text { et al. 2011) } \\
\text { Patrono et al } 2015 \text { ((Patrono } \\
\text { et al. 2015) }\end{array}$ \\
\hline RIKEN Wako & Protons, $\alpha$ & 3-4 MeV & $\begin{array}{l}\text { Iwai et al } 2008 \text { (Iwai et al. } \\
\text { 2008) }\end{array}$ \\
\hline SNAKE Munich & Protons, $\alpha, \mathrm{Li}, \mathrm{O}, \mathrm{Si}$, & $\begin{array}{l}\text { 4-28 MeV } \\
1-10.5 \mathrm{MeV} \mathrm{u}^{-1}\end{array}$ & $\begin{array}{l}\text { Hauptner et al } 2004 \text { (Dollinger } \\
\text { et al. 2005) } \\
\text { Drexler et al } 2015 \text { (Drexler \& } \\
\text { Ruiz-Gómez 2015) }\end{array}$ \\
\hline GSI Darmstadt & Protons, $\alpha, C$ to $U$ & 1.4-11.4 MeV u ${ }^{-1}$ & $\begin{array}{l}\text { Heiss et al } 2006 \text { (Heiss et al. } \\
\text { 2006) }\end{array}$ \\
\hline Jaeri Takasaki & A, C, Ne, Ar & 12.5-17.5 $\mathrm{MeV} \mathrm{u}^{-1}$ & $\begin{array}{l}\text { Funayama et al } 2005 \\
\text { (Funayama et al. 2005) }\end{array}$ \\
\hline Leipzig & $\mathrm{H}, \mathrm{He}$ & $2.25 \mathrm{MeV}$ & $\begin{array}{l}\text { Butz el al } 2000 \text { (Butz et al. } \\
\text { 2000) }\end{array}$ \\
\hline
\end{tabular}


Electron microbeam

Pacific Northwest

National Laboratory
Electrons

Variable energy

Sowa et al 2005 (Sowa et al. 2005)

Table 2 An updated list for X-ray microbeam facilities

\begin{tabular}{|c|c|c|}
\hline Facility & Energy Range & Reference \\
\hline Columbia University & $\begin{array}{l}\text { Ti soft X-ray } 4.5 \\
\text { keV }\end{array}$ & $\begin{array}{l}\text { Harken et al } 2011 \text { (Harken et al } \\
\text { 2011) }\end{array}$ \\
\hline $\begin{array}{l}\text { Brookhaven National } \\
\text { Laboratory }\end{array}$ & $2.584 \mathrm{GeV}$ & $\begin{array}{l}\text { Dilmanian et al } 2001 \\
\text { (Dilmanian et al. 2003) }\end{array}$ \\
\hline Queen's University Belfast & $\begin{array}{l}\text { K-shell C soft X- } \\
\text { ray } 287 \mathrm{eV}\end{array}$ & $\begin{array}{l}\text { Folkard et al } 1997 \text { (Folkard et } \\
\text { al. 2001b) }\end{array}$ \\
\hline $\begin{array}{l}\text { European Synchrotron (ESRF), } \\
\text { Grenoble }\end{array}$ & & $\begin{array}{l}\text { Alagoz et al } 2016 \text { (Alagoz et al. } \\
\text { 2016) }\end{array}$ \\
\hline $\begin{array}{l}\text { Australian Synchrotron } \\
\text { Imaging and Medical Be } \\
\text { (IMBL) }\end{array}$ & $125 \mathrm{keV}$ & $\begin{array}{l}\text { Crosbie et al } 2010 \text { (Crosbie et } \\
\text { al. 2010) } \\
\text { Gagliardi et al } 2015 \text { (Gagliardi } \\
\text { et al. 2015) }\end{array}$ \\
\hline Institute of Cancer Research & $225 \mathrm{kVp}$ & $\begin{array}{l}\text { Bartzsch et al } 2016 \text { (Bartzsch et } \\
\text { al. 2016) }\end{array}$ \\
\hline KEK IMSS Photon Factory & $2.34 \mathrm{keV}$ & $\begin{array}{l}\text { Kaminaga et al } 2016 \text { (Kaminaga } \\
\text { et al. 2016) }\end{array}$ \\
\hline
\end{tabular}



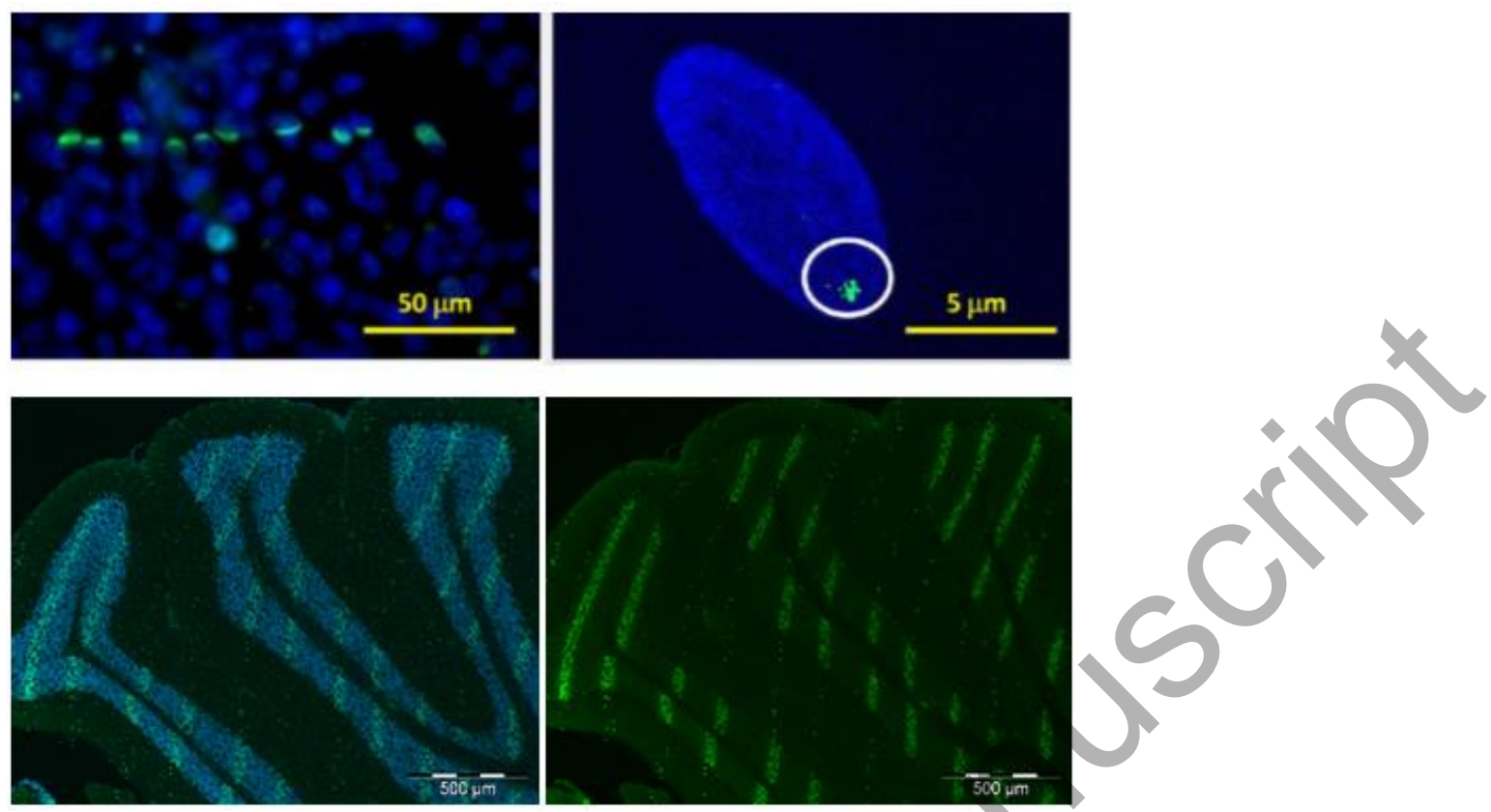

Figure 3 Different magnitude of biological effects measured using $\mathrm{VH}_{2} \mathrm{AX}$ used as a DNA damage marker after microbeam irradiation using $C K$-shell Soft X-ray used a) in scanning mode and $b$ ) with a dose of 2 Gy measured and delivered to cell nucleus in the outlined region; synchrotron X-ray used to target the cerebellum in c) and d), with an entrance dose of $350 \mathrm{~Gy}$ 